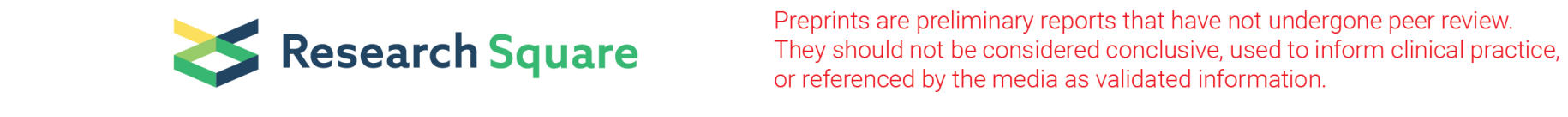

\title{
latrogenic Dissemination Of initially Resectable Lung Cancer After Transthoracic Fine-needle Biopsy : who is to Be Blamed?
}

\author{
Yuan-Yuan Liu \\ Xuzhou Central Hospital \\ Longbo Gong \\ Xuzhou Central Hospital \\ Wenbin Wu \\ Xuzhou Central Hospital \\ Miao Zhang ( $\nabla$ zhangmiaodr@163.com ) \\ Xuzhou Central Hospital https://orcid.org/0000-0001-7431-5986
}

\section{Case report}

Keywords: Lung cancer, Aspiration, Core biopsy, Patient-physician relationship, Medical decision making, Artificial intelligence

Posted Date: June 29th, 2020

DOl: https://doi.org/10.21203/rs.3.rs-37775/v1

License: (c) (i) This work is licensed under a Creative Commons Attribution 4.0 International License. Read Full License 


\section{Abstract}

Background: Percutaneous fine-needle biopsy is a well-established procedure for the diagnosis of lung lesions. However, tumor dissemination after transthoracic biopsy is potentially unpreventable.For radiographical malignant localized tumors, the optimal choice (a timely surgery or preoperative biopsy) is debatable.

Case Presentation: A 57-year-old male patient was admitted due to a radiographical malignant but initially resectable lung tumor in the chest images. Although lobectomy, instead of biopsy, was recommended by the multidisciplinary consultation team, the patient declared that he would ask for compensation if the pulmonary lesion was benign. He developed pleural and pericardial effusion about 9 months after the first biopsy, which failed to yield a definite diagnosis. Chest tube drainage revealed malignant tumor cells. Finally, unresectable stage $\otimes$ primary lung adenocarcinoma was confirmed by another biopsy. Therefore, chemotherapy plus targeted agents was administered.The patient was lost to follow up 1 month later.

Conclusions: A timely resection rather than biopsy of the lung lesion suspicious for cancer should be considered when appropriate. In addition,how to avoid the negative effect of patient-physician relationship in medical decision making warrants further ethical and clinical studies.

\section{Background}

Fine needle aspiration biopsy is a useful procedure for the diagnosis of lung cancer. However, controversy still remains as to whether it should be employed in patients with undiagnosed and operable lesions suspicious for lung cancer. A potential complication of computed tomography (CT)-guided transthoracic fine-needle biopsy is the dissemination of tumor cells along the needle track, resulting in pleural and chest wall metastasis[1,2]. In thoery, a timely operationrather than preoperative biopsy for pahtological diagnosis seems reasonable for selected patients.

Physicians could explain what should be done and the patients could freely express their opinions regarding treatment choice. Nevertheless, surgical decision-making is sometimes inevitably hampered by a few absurd reasons including the quality of patientphysician relationship and the personality of the patients. For example, a timely resection of the initially localized tumor would be suspended or cancelled if the patient distrusts the physician. Thus, in addition to identifying reliable and the optimal individualizedmanagement options, it is crucial to improve the patient-physician relationship. To the best of our knowledge, the negative effect of patient-physician conflict on medical decision is not uncommon in the real-world settings. Who is to be blamed?

Herein we presented a case of pleural dissemination of initially resectable lung adenocarcinoma after percutaneous fine-needle biopsy, followed by a brief literature review regarding the usefulness and potential risks of transthoracic biopsy.

\section{Case presentation}

The clinical data of the patient was presented anonymously for privacy concern. A 57-year-old male patient was admitted on April 4, 2016 because of cough for about 1 month, without fever, hemoptysis, hoarseness, chest distress, thorcalgia, dorsalgia, or significant weight loss. The physical examination showed nothing abnormal. The serum carcinoembryonic antigen, neuron-specific enolase, squamous cell carcinoma antigen, and cytokeratin-19 fragment were all in normal range. Further chest CT revealed a pulmonary lesion in the left upper lobe, measuring $43 \mathrm{~mm} \times 19 \mathrm{~mm}$ in size (Fig. 1A). It was in suspicious of lung cancerdue to the obvious spiculation margin and pleural tag signs. Distal metastasis was excluded by preoperative work-up including abdomen $\mathrm{CT}$, cranial magnetic resonance and bone emission CT. Based on these findings, the case was staged as cT2bNOM0 ( $\triangle \mathrm{A})$ according to the 8th edition of tumor node metastasis staging system for lung cancer[3].

After a multidisciplinary consultation, uniportal thoracoscopic lobectomy and mediastinal lymph node sampling was recommended. The patient was informed that the lung tumor was probably malignancy, and biopsy was correlated with the potential risk of tumor dissemination. Nevertheless, the patient declared that he would ask for reimbursement from the physicians after the operation if the lesion turned out to be benign. Surgery was therefore cancelled. However, a CT-guided percutaneous core biopsy with an 18-gauge cutting needle failed to yield a pathological diagnosis of lung cancer. The alternative management including a second biopsy and intensive follow up were introduced. Then the patient was discharged from the hospital. 
During the follow up, his CT on June 13, 2016 showed that the pulmonary lesion was slightly enlarged (Fig. 1B). But the physicians still did not perform surgery because of the fear of patient-physician conflict. The patient was readmitted about 9 months after the first transthoracic biopsy on January 9, 2017 due to gradually aggravated chest tightness. Unfortunately, the pleural and pericardial perfusion was indicated (Fig. 1C), and malignant cells were detected in the pleural effusion after chest tube drainage. The second CT-guided biopsy revealed the pathological diagnosis of lung adenocarcinoma (cT4NxM1a, $\triangle A$ ). Systemic chemotherapy plus targeted agents was conducted accordingly. Thereafter, the patient was transferred to another hospital after the first cycle of antitumor treatment.

\section{Discussion And Conclusions}

The present report aimed to improve both clinicians and patients' understanding of the risk of CT-guided biopsy, as well as the importance role of patient-physician relationship in medical decision making.

The radiographical features of pulmonary nodules including short axis, contour, concavity, texture, location, fissure attachment, lobulation; while spiculation can be used with size-based measures to enhance prediction accuracy and to reduce false-positives[4]. Positron Emission Tomography-CT (PET-CT) plays an important role in the diagnosis, staging, response assessment and followupfor non-small cell lung cancer (NSCLC)patients [5]. The diagnostic accuracy of contrast-enhanced CT and PET-CT is 0.58 and 0.9 respectively in identifying malignant solitary pulmonary nodules (diameter range $8-30 \mathrm{~mm}$ )[6].

In addition to the radiological images, percutaneous fine-needle biopsy is widely used for cytological diagnosis of bronchogenic carcinoma. We searched PubMed, Web of Science, Scopus, Embase and Google Scholar for relevant reports up to January 2020. Key words and MeSH terms in title or abstract including "biopsy" or "puncture" or "CT-guided" and "pulmonary" or "lung" were used. No restriction was made regarding the publication language. Finally a total of 15 studies indicating the performance of CT-guided transthoracic needle biopsy were summarized in Table 1.The diagnostic accuracy of CT-guided aspiration biopsy of large nodules $(>1.5 \mathrm{~cm})$ and small nodules $(\leq 1.5 \mathrm{~cm})$ was $96 \%$ and $74 \%$, respectively[7].In addition, the diagnostic accuracy of CT-guided needle biopsy was significantly improved for large $(>10 \mathrm{~mm}$ ) lesion size and short ( $<$ or $=40 \mathrm{~mm}$ ) needle path length[9]. Factors such as the acquisition of two or fewer specimens, lesions in the lower lobe, malignant lesions, and lesions measuring $\leq 1.0 \mathrm{~cm}$ or $\geq 3.1 \mathrm{~cm}$ significantly increased the rate of diagnostic failure[10]. Core biopsy is a preferred method as it gives a higher percentage of representative samples than fine-needle aspiration biopsy[12].Furthermore, the major complication rates for core biopsy and fine needle aspiration were $5.7 \%$ and $4.4 \%$, respectively. Smaller nodule diameter, larger needle diameter and increased traversed lung parenchyma were risk factors for complications[22].Based on the available evidence, CT-guided percutaneous lung biopsy for pulmonary nodules is afeasible and efficient diagnostic method.

However, dissemination of cancer cells along needle track can make a potentially resectable localized lung cancer to be unresectable. Previous reports of lung tumor dissemination or implantation after biopsy were summarized in Table 2. The largest reported sample from Japan indicated that the incidence of tumor seeding at the site of the puncture route after fine-needle biopsy was about $0.06 \%[34]$; whereas the interval between the initiation of biopsy and the diagnosis of implantation/metastasis was reported to be 4-13 months[26, 30,36]. Therefore, post-biopsy radiographic examination was necessary.Furthermore, transthoracic fine-needle biopsy should not be performed in patients with sub-pleural pure solid nodules who were suspected of having NSCLC[40]. Other studies showed that CT-guided lung biopsy with a coaxial needle did not seem to cause pleural dissemination or pleural recurrence[35,41]; whereas visceral pleural invasion was responsible for tumor relapse.

On the other hand, chest wall implantation of lung adenocarcinoma at the drainage tube site has also been reported[43]. To prevent such tumor seeding at the time of thoracotomy, the pleural cavity should be washed out routinely with a massive volume of saline prior to closure of the chest wall. Despite the reports of malignant spread along the needle track, preoperative biopsy does not affect the survival in stage I NSCLC patients[44]. In addition, subcutaneous implantation of tumor cells along the needle track has also been reported in bladder, urethra, and prostate, adrenal, pancreatic, thyroid, parathyroid, and hepatocellularcarcinoma[28, 45-52]. Therefore, percutaneous fine-needle biopsy of the suspicious malignant lesions as indicated in radiographical images should not be performed indiscriminately but be reserved.

Moreover, the patient-physician trust is the foundation of clinical practice. The incidence of patient-reported regret over the decision to major abdominal and thoracic operations is 37\%[53]. The factors most often associated with regret include type of surgery, 
disease-specific quality of life[54], decisional conflict and lower satisfaction with the decision, adverse physical health outcomes, and greater anxiety levels[55].

Furthermore, healthcare workplace violence is an underreported problem that has been largely ignored. Deterioration of patientphysician relationship had worsened and the violence against the healthcare workers emerged as a visible risk to reasonable decision-making[56]. One of the most prominent forces driving patient-physician mistrust is a patient perception of injustice within the medical sphere due to knowledge imbalances and conflicts of interest. The mistrust leads to attacks against physicians[57]. A cross-sectional survey indicated that $34.4 \%$ of healthcare workers reported verbal or physical violence in the preceding 12 months, along with $13.5 \%$ of physical assault[58]. A meta-analysis showed that the prevalence of healthcare workplace violence is especially high in Asian and North American countries[59]. On the contrary, patients are also afraid that an important diagnosis will be missed or delayed through laziness, or incompetence of the physicians[60]. Moral, regulatory and legal responses are needed to restore the patient-physician trust. Generally speaking, surgical decision-making is impaired by time constraints, uncertainty, complexity, decision fatigue, hypothetical-deductive reasoning and bias. Integration of artificial intelligence with surgical decision-making has the potential to diminish overtreatment[61].

For the present case, a timely minimally invasive lobectomy was recommended on his first admission after multidisciplinary evaluation. However, the physicians intentionally gave upthe operation to avoid potential patient-physician conflict, as the patient declared that he would demand compensation if the lesion turned out to be benign. In the real-world settings, some doctors do not know how to face the complex relationship with their patients. Meanwhile,the fear of violence impairs the decision-making deliberately. Therefore, the choice of treatment is only partly provided based on the publishedofficial guidelines and consensus recommendations.

In summary, tumor implantation or dissemination afterfine-needle biopsy is somewhatinevitable and unpreventable. A timely operation should always be considered for radiographicalmalignantandresectable lung lesions, providing that the potential patientphysician conflict could be avoided efficiently.

\section{List Of Abbreviations}

CT, computed tomography; MRI, magnetic resonance imaging; PET-CT, Positron Emission Tomography-Computed Tomography; NSCLC, non-small-cell lung cancer

\section{Declarations}

\section{Ethics approval and consent to participate}

This report was approved by the Institutional Review Board of Xuzhou Central Hospital, and written informed consent was obtained from the patient.

\section{Consent for publication}

Written informed consent was obtained from the patient for publication of this report and any accompanying images.

\section{Availability of data and materials}

The data of the present case is available from the corresponding author on reasonable request.

\section{Competing interests}

The authors declare that they have no competing interests.

\section{Funding}

Not applicable.

\section{Authors' contributions}


MZ performed the surgery and wrote this paper. YYL contributed to the preparation of the figures and tables. All authors contributed to preparation of the paper and to the perioperative treatment of the patient. All authors approved the final manuscript.

\section{Acknowledgements}

Not applicable.

\section{References}

1. Matsuguma $H$, Nakahara $R$, Kondo $T$, et al. Risk of pleural recurrence after needle biopsy in patients with resected early stage lung cancer. Ann Thorac Surg. 2005;80:2026-2031.

2. Kara M, Alver G, Sak S D, et al. Implantation metastasis caused by fine needle aspiration biopsy following curative resection of stage IB non-small cell lung cancer. Eur J Cardiothorac Surg. 2001;20:868-870.

3. Lancia A, Merizzoli E, Filippi A R. The 8(th) UICC/AJCC TNM edition for non-small cell lung cancer staging: getting off to a flying start?. Ann Transl Med. 2019;7:S205.

4. Liu Y, Balagurunathan Y, Atwater T, et al. Radiological Image Traits Predictive of Cancer Status in Pulmonary Nodules. Clin Cancer Res. 2017;23:1442-1449.

5. Volpi S, Ali J M, Tasker A, et al. The role of positron emission tomography in the diagnosis, staging and response assessment of non-small cell lung cancer. Ann Transl Med. 2018;6:95.

6. Dabrowska M, Krenke R, Korczynski P, et al. Diagnostic accuracy of contrast-enhanced computed tomography and positron emission tomography with 18-FDG in identifying malignant solitary pulmonary nodules. Medicine (Baltimore). 2015;94:e666.

7. Li H, Boiselle P M, Shepard J O, et al. Diagnostic accuracy and safety of CT-guided percutaneous needle aspiration biopsy of the lung: comparison of small and large pulmonary nodules. AJR Am J Roentgenol. 1996;167:105-109.

8. Tsukada H, Satou T, Iwashima A, et al. Diagnostic accuracy of CT-guided automated needle biopsy of lung nodules. AJR Am J Roentgenol. 2000;175:239-243.

9. Ohno Y, Hatabu H, Takenaka D, et al. CT-guided transthoracic needle aspiration biopsy of small ( $<$ or $=20 \mathrm{~mm}$ ) solitary pulmonary nodules. AJR Am J Roentgenol. 2003;180:1665-1669.

10. Hiraki T, Mimura H, Gobara H, et al. CT fluoroscopy-guided biopsy of 1,000 pulmonary lesions performed with 20-gauge coaxial cutting needles: diagnostic yield and risk factors for diagnostic failure. Chest. 2009;136:1612-1617.

11. Wu R H, Tzeng W S, Lee W J, et al. CT-guided transthoracic cutting needle biopsy of intrathoracic lesions: comparison between coaxial and single needle technique. Eur J Radiol. 2012;81:e712-716.

12. Beslic S, Zukic F, Milisic S. Percutaneous transthoracic CT guided biopsies of lung lesions; fine needle aspiration biopsy versus core biopsy. Radiol Oncol. 2012;46:19-22.

13. Choi S H, Chae E J, Kim J E, et al. Percutaneous CT-guided aspiration and core biopsy of pulmonary nodules smaller than $1 \mathrm{~cm}$ : analysis of outcomes of 305 procedures from a tertiary referral center. AJR Am J Roentgenol. 2013;201:964-970.

14. Lee S M, Park C M, Lee K H, et al. C-arm cone-beam CT-guided percutaneous transthoracic needle biopsy of lung nodules: clinical experience in 1108 patients. Radiology. 2014;271:291-300.

15. Yang W, Sun W, Li Q, et al. Diagnostic Accuracy of CT-Guided Transthoracic Needle Biopsy for Solitary Pulmonary Nodules. PLoS One. 2015;10:e0131373.

16. Wang Y, Jiang F, Tan X, et al. CT-guided percutaneous transthoracic needle biopsy for paramediastinal and nonparamediastinal lung lesions: Diagnostic yield and complications in 1484 patients. Medicine (Baltimore). 2016;95:e4460.

17. Li G C, Fu Y F, Cao W, et al. Computed tomography-guided percutaneous cutting needle biopsy for small $(</=20 \mathrm{~mm})$ lung nodules. Medicine (Baltimore). 2017;96:e8703.

18. Tian P, Wang Y, Li L, et al. CT-guided transthoracic core needle biopsy for small pulmonary lesions: diagnostic performance and adequacy for molecular testing. J Thorac Dis. 2017;9:333-343.

19. Jeon M C, Kim J O, Jung S S, et al. CT-Guided Percutaneous Transthoracic Needle Biopsy Using the Additional Laser Guidance System by a Pulmonologist with 2 Years of Experience in CT-Guided Percutaneous Transthoracic Needle Biopsy. Tuberc Respir Dis (Seoul). 2018; 81:330-338. 
20. Ahn J H, Jang J G. Initial Experience in CT-Guided Percutaneous Transthoracic Needle Biopsy of Lung Lesions Performed by a Pulmonologist. J Clin Med. 2019;8:821.

21. Tosi D, Mendogni P, Carrinola R, et al. CT-guided fine-needle aspiration biopsy of solitary pulmonary nodules under $15 \mathrm{~mm}$ in diameter: time for an afterthought?. J Thorac Dis. 2019;11:724-731.

22. Heerink W J, De Bock G H, De Jonge G J, et al. Complication rates of CT-guided transthoracic lung biopsy: meta-analysis. Eur Radiol. 2017;27:138-148.

23. Wolinsky H, Lischner M W. Needle track implantation of tumor after percutaneous lung biopsy. Ann Intern Med. 1969;71:359362.

24. Sinner W N, Zajicek J. Implantation metastasis after percutaneous transthoracic needle aspiration biopsy. Acta Radiol Diagn (Stockh). 1976;17:473-480.

25. Woyke S, Mazuryk R, Frycz L. [Implantation of neoplastic tissue into the chest wall as a complication of transthoracic thinneedle aspiration biopsy]. Pneumonol Pol. 1982;50:115-119.

26. Moloo Z, Finley R J, Lefcoe M S, et al. Possible spread of bronchogenic carcinoma to the chest wall after a transthoracic fine needle aspiration biopsy. A case report. Acta Cytol. 1985;29:167-169.

27. Seyfer A E, Walsh D S, Graeber G M, et al. Chest wall implantation of lung cancer after thin-needle aspiration biopsy. Ann Thorac Surg 1989;48:284-286.

28. Voravud N, Shin D M, Dekmezian R H, et al. Implantation metastasis of carcinoma after percutaneous fine-needle aspiration biopsy. Chest.1992;102:313-315.

29. Paik H C, Lee D Y, Lee H K, et al. Chest wall implantation of carcinoma after fine needle aspiration biopsy. Yonsei Med J. 1994;35:349-354.

30. Sing R F, Kefalides P T, Mette S A, et al. Chest wall metastasis after percutaneous fine-needle aspiration biopsy. J Am Osteopath Assoc. 1996;96:546-547.

31. Raftopoulos Y, Furey W W, Kacey D J, et al. Tumor implantation after computed tomography-guided biopsy of lung cancer. J Thorac Cardiovasc Surg. 2000;119:1288-1289.

32. Yoshikawa T, Yoshida J, Nishimura M, et al. Lung cancer implantation in the chest wall following percutaneous fine needle aspiration biopsy. Jpn J Clin Oncol. 2000;30:450-452.

33. Kim J H, Kim Y T, Lim H K, et al. Management for chest wall implantation of non-small cell lung cancer after fine-needle aspiration biopsy. Eur J Cardiothorac Surg. 2003;23:828-832.

34. Tomiyama N, Yasuhara Y, Nakajima Y, et al. CT-guided needle biopsy of lung lesions: a survey of severe complication based on 9783 biopsies in Japan. Eur J Radiol. 2006;59:60-64.

35. Sano Y, Date H, Toyooka S, et al. Percutaneous computed tomography-guided lung biopsy and pleural dissemination: an assessment by intraoperative pleural lavage cytology. Cancer. 2009;115:5526-5533.

36. Ibukuro K, Tanaka R, Takeguchi T, et al. Air embolism and needle track implantation complicating CT-guided percutaneous thoracic biopsy: single-institution experience. AJR Am J Roentgenol. 2009;193:W430-436.

37. Scotti V, Di Cataldo V, Falchini M, et al. Isolated chest wall implantation of non-small cell lung cancer after fine-needle aspiration: a case report and review of the literature. Tumori. 2012;98:126e-129e.

38. Schreiner A M, Jones J G, Swistel A J, et al. Transthoracic fine needle aspiration resulting in implantation metastasis in the superficial tissues of the breast. Cytopathology. 2013;24:58-60.

39. Kim Y D, Lee B Y, Min K O, et al. Intrapulmonary recurrence after computed tomography-guided percutaneous needle biopsy of stage I lung cancer. J Thorac Dis. 2014;6:1004-1006.

40. Kashiwabara K, Semba H, Fujii S, et al. Preoperative Percutaneous Transthoracic Needle Biopsy Increased the Risk of Pleural Recurrence in Pathological Stage I Lung Cancer Patients With Sub-pleural Pure Solid Nodules. Cancer Invest. 2016;34:373-377.

41. Ahn S Y, Yoon S H, Yang B R, et al. Risk of pleural recurrence after percutaneous transthoracic needle biopsy in stage I nonsmall-cell lung cancer. Eur Radiol. 2019;29:270-278.

42. Huang L K, Tsai C H. Chest wall implantation of lung cancer following percutaneous transthoracic biopsy. Postgrad Med J. 2019;95:509-510. 
43. Sugi K, Nawata K, Ueda K, et al. Chest wall implantation of lung cancer at the drainage tube site: report of a case. Surg Today. 1997;27:666-668.

44. Wisnivesky J P, Henschke C I, Yankelevitz D F. Diagnostic percutaneous transthoracic needle biopsy does not affect survival in stage I lung cancer. Am J Respir Crit Care Med. 2006;174:684-688.

45. Takahashi T, Mori K, Suga Y, et al. [A case of pulmonary metastasis from carcinosarcoma of uterus with subcutaneous implantation of tumor cells along the needle tract after percutaneous needle biopsy of lung]. Nihon Kyobu Shikkan Gakkai Zasshi. 1992;30:1333-1337.

46. Nyland T G, Wallack S T, Wisner E R. Needle-tract implantation following us-guided fine-needle aspiration biopsy of transitional cell carcinoma of the bladder, urethra, and prostate. Vet Radiol Ultrasound. 2002;43:50-53.

47. lida T, Adachi T, Nakagaki S, et al. EDUCATION AND IMAGING. Gastrointestinal: Needle tract implantation after endoscopic ultrasound-guided fine-needle aspiration of a pancreatic adenocarcinoma. J Gastroenterol Hepatol. 2016;31:285.

48. Sakurada A, Hayashi T, Ono M, et al. A case of curatively resected gastric wall implantation of pancreatic cancer caused by endoscopic ultrasound-guided fine-needle aspiration. Endoscopy. 2015;47:E198-199.

49. Ito Y, Asahi S, Matsuzuka F, et al. Needle tract implantation of follicular neoplasm after fine-needle aspiration biopsy: report of a case. Thyroid. 2006;16:1059-1062.

50. Agarwal G, Dhingra S, Mishra S K, et al. Implantation of parathyroid carcinoma along fine needle aspiration track. Langenbecks Arch Surg. 2006;391:623-626.

51. Ito $\mathrm{Y}$, Tomoda $\mathrm{C}$, Uruno $\mathrm{T}$, et al. Needle tract implantation of papillary thyroid carcinoma after fine-needle aspiration biopsy. World J Surg. 2005;29:1544-1549.

52. Kim S H, Lim H K, Lee W J, et al. Needle-tract implantation in hepatocellular carcinoma: frequency and CT findings after biopsy with a 19.5-gauge automated biopsy gun. Abdom Imaging. 2000;25:246-250.

53. Wilson A, Winner $M$, Yahanda A, et al. Factors associated with decisional regret among patients undergoing major thoracic and abdominal operations. Surgery. 2017;161:1058-1066.

54. Wilson A, Ronnekleiv-Kelly S M, Pawlik T M. Regret in Surgical Decision Making: A Systematic Review of Patient and Physician Perspectives. World J Surg. 2017;41:1454-1465.

55. Becerra Perez M M, Menear M, Brehaut J C, et al. Extent and Predictors of Decision Regret about Health Care Decisions: A Systematic Review. Med Decis Making. 2016;36:777-790.

56. Phillips J P. Workplace Violence against Health Care Workers in the United States. N Engl J Med. 2016;374:1661-1669.

57. Tucker J D, Cheng Y, Wong B, et al. Patient-physician mistrust and violence against physicians in Guangdong Province, China: a qualitative study. BMJ Open. 2015;5:e008221.

58. Rosenthal L J, Byerly A, Taylor A D, et al. Impact and Prevalence of Physical and Verbal Violence Toward Healthcare Workers. Psychosomatics. 2018;59:584-590.

59. Liu J, Gan Y, Jiang H, et al. Prevalence of workplace violence against healthcare workers: a systematic review and metaanalysis. Occup Environ Med. 2019;76:927-937.

60. Heath I. Role of fear in overdiagnosis and overtreatment-an essay by lona Heath. BMJ. 2014;349:g6123.

61. Loftus T J, Tighe P J, Filiberto A C, et al. Artificial Intelligence and Surgical Decision-Making. JAMA Surg. 2019;154:E1-11.DOI: 10.1001/jamasurg.2019.4917

\section{Tables}


Table 1

Previous studies regarding the diagnostic performance of transthoracic fine-needle lung biopsy

\begin{tabular}{|c|c|c|c|c|c|c|c|c|}
\hline $\begin{array}{l}\text { Author, } \\
\text { year }\end{array}$ & No. of nodules & $\begin{array}{l}\text { Tumor } \\
\text { size } \\
(\mathrm{cm})\end{array}$ & $\begin{array}{l}\text { Biopsy } \\
\text { methods }\end{array}$ & $\begin{array}{l}\text { Needle } \\
\text { size } \\
\text { (gauge) }\end{array}$ & $\begin{array}{l}\text { False-negative } \\
(\%)\end{array}$ & $\begin{array}{l}\text { Diagnostic } \\
\text { failure (\%) }\end{array}$ & $\begin{array}{l}\text { Sensitivity } \\
(\%)\end{array}$ & $\begin{array}{l}\text { Specificity } \\
(\%)\end{array}$ \\
\hline \multirow{2}{*}{$\begin{array}{l}\mathrm{Li}, \\
1996^{[7]}\end{array}$} & 27 & $\leq 1.5$ & \multirow[t]{2}{*}{ Aspiration } & \multirow[t]{2}{*}{ NA } & \multirow[t]{2}{*}{ NA } & 26 & \multirow[t]{2}{*}{ NA } & \multirow[t]{2}{*}{ NA } \\
\hline & 70 & $>1.5$ & & & & 4 & & \\
\hline $\begin{array}{l}\text { Tsukada, } \\
2000^{[8]}\end{array}$ & 138 & $\begin{array}{l}2.3 \pm 1.2 \\
(0.6- \\
7.0)\end{array}$ & $\begin{array}{l}\text { Core } \\
\text { biopsy }\end{array}$ & NA & $\begin{array}{l}15.22 \\
(21 / 138)\end{array}$ & 17.4 & 76.9 & 93.6 \\
\hline $\begin{array}{l}\text { Ohno, } \\
2003^{[9]}\end{array}$ & 162 & $\leq 2$ & Aspiration & NA & NA & 22.8 & NA & NA \\
\hline $\begin{array}{l}\text { Hiraki, } \\
2009^{[10]}\end{array}$ & 1000 & $\begin{array}{l}2.3 \pm 1.5 \\
(0.4- \\
11.4)\end{array}$ & $\begin{array}{l}\text { Core } \\
\text { biopsy }\end{array}$ & 20 & $\begin{array}{l}4.10 \\
(41 / 1000)\end{array}$ & 4.8 & 94.2 & 99.1 \\
\hline \multirow[t]{2}{*}{$\begin{array}{l}\text { Wu, } \\
2012^{[11]}\end{array}$} & 98 & \multirow[t]{2}{*}{ NA } & $\begin{array}{l}\text { single } \\
\text { needle } \\
\text { cutting }\end{array}$ & \multirow[t]{2}{*}{18} & \multirow[t]{2}{*}{ NA } & \multirow[t]{2}{*}{2} & 96.9 & 100 \\
\hline & 100 & & coaxial & & & & 96.4 & 100 \\
\hline \multirow{2}{*}{$\begin{array}{l}\text { Beslic, } \\
2012^{[12]}\end{array}$} & 147 & \multirow{2}{*}{$\begin{array}{l}2.9 \\
(1.2- \\
6.3)\end{array}$} & Aspiration & $20-22$ & \multirow[t]{2}{*}{ NA } & \multirow[t]{2}{*}{ NA } & NA & NA \\
\hline & 95 & & $\begin{array}{l}\text { Core } \\
\text { biopsy }\end{array}$ & 14 & & & 96 & 100 \\
\hline $\begin{array}{l}\text { Choi, } \\
2013^{[13]}\end{array}$ & 305 & $\leq 1$ & $\begin{array}{l}\text { Core } \\
\text { biopsy/ } \\
\text { aspiration }\end{array}$ & 20 & $3.61(11 / 305)$ & 5.0 & 93.1 & 98.8 \\
\hline $\begin{array}{l}\text { Lee, } \\
2014^{[14]}\end{array}$ & 1153 & $2.7 \pm 1.7$ & $\begin{array}{l}\text { Core } \\
\text { biopsy }\end{array}$ & 18 & $\begin{array}{l}2.86 \\
(33 / 1153)\end{array}$ & 3.0 & 95.7 & 100 \\
\hline $\begin{array}{l}\text { Yang, } \\
2015^{[15]}\end{array}$ & 311 & NA & $\begin{array}{l}\text { Core } \\
\text { biopsy }\end{array}$ & 18 & $3.86(12 / 311)$ & 7.1 & 95.3 & 95.7 \\
\hline \multirow[t]{2}{*}{$\begin{array}{l}\text { Wang, } \\
2016^{[16]}\end{array}$} & $\begin{array}{l}195 \\
\text { paramediastinal }\end{array}$ & NA & $\begin{array}{l}\text { Core } \\
\text { biopsy }\end{array}$ & 18 & $2.56(5 / 195)$ & 4.6 & 95.6 & 100 \\
\hline & $\begin{array}{l}1289 \\
\text { nonparamediastinal }\end{array}$ & & & & $3.41(44 / 1289)$ & 5.3 & 94.2 & 100 \\
\hline $\begin{array}{l}\mathrm{Li}, \\
2017^{[17]}\end{array}$ & 141 & $\leq 2$ & $\begin{array}{l}\text { Core } \\
\text { biopsy }\end{array}$ & 18 & 0 & 3.9 & 94.4 & 100 \\
\hline $\begin{array}{l}\text { Tian, } \\
2017^{[18]}\end{array}$ & 560 & $\begin{array}{l}1.8 \pm 0.6 \\
(\leq 3)\end{array}$ & $\begin{array}{l}\text { Core } \\
\text { biopsy }\end{array}$ & 18 & NA & 5.4 & 92.0 & 98.6 \\
\hline $\begin{array}{l}\text { Jeon, } \\
2018^{[19]}\end{array}$ & 238 & NA & NA & NA & 3.78 (9/238) & 3.8 & 94.4 & 100 \\
\hline $\begin{array}{l}\text { Ahn, } \\
2019^{[20]}\end{array}$ & 224 & NA & $\begin{array}{l}\text { Core } \\
\text { biopsy }\end{array}$ & 20 & NA & 3.1 & 96.1 & 100 \\
\hline $\begin{array}{l}\text { Tosi, } \\
2019^{[21]}\end{array}$ & 68 & $\leq 1.5$ & Aspiration & 22,23 & NA & 27.9 & 100 & 100 \\
\hline
\end{tabular}


Table 2

Previous reports oftumor dissemination/implantationafter transthoracic fine-needle lung biopsy

\begin{tabular}{|c|c|c|c|c|c|c|}
\hline $\begin{array}{l}\text { First author, } \\
\text { year }\end{array}$ & $\begin{array}{l}\text { Biopsy } \\
\text { methods }\end{array}$ & $\begin{array}{l}\text { Needle } \\
\text { size } \\
\text { (gauge) }\end{array}$ & Pattern of tumor dissemination & $\begin{array}{l}\text { Number } \\
\text { of } \\
\text { patients }\end{array}$ & $\begin{array}{l}\text { Incidence of } \\
\text { tumor } \\
\text { dissemination }\end{array}$ & $\begin{array}{l}\text { The interval } \\
\text { between biopsy and } \\
\text { diagnosis of } \\
\text { dissemination }\end{array}$ \\
\hline $\begin{array}{l}\text { Wolinsky, } \\
\text { 1969[23] }\end{array}$ & NA & NA & Needle track implantation & 1 & - & NA \\
\hline $\begin{array}{l}\text { Sinner, } \\
\text { 1976[24] }\end{array}$ & Aspiration & NA & needle track implantation & 1 & $\begin{array}{l}0.08 \% \\
(1 / 1264)\end{array}$ & NA \\
\hline $\begin{array}{l}\text { Woyke, } \\
\text { 1982[25] }\end{array}$ & NA & NA & Chest wall implantation & 1 & - & NA \\
\hline $\begin{array}{l}\text { Moloo, } \\
\text { 1985[26] }\end{array}$ & NA & NA & chest wall metastasis & 1 & - & 13 months \\
\hline $\begin{array}{l}\text { Seyfer, } \\
1989[27]\end{array}$ & aspiration & NA & Chest wall implantation & 1 & - & NA \\
\hline $\begin{array}{l}\text { Voravud, } \\
\text { 1992[28] }\end{array}$ & aspiration & NA & Chest wall implantation & 1 & - & NA \\
\hline $\begin{array}{l}\text { Paik, } \\
\text { 1994[29] }\end{array}$ & aspiration & NA & Chest wall implantation & 1 & & NA \\
\hline $\begin{array}{l}\text { Sing, } \\
1996[30]\end{array}$ & aspiration & NA & chest wall metastasis & 1 & - & 4 months \\
\hline $\begin{array}{l}\text { Raftopoulos, } \\
2000[31]\end{array}$ & NA & NA & Tumor implantation & 1 & - & NA \\
\hline $\begin{array}{l}\text { Yoshikawa, } \\
2000[32]\end{array}$ & aspiration & 19 & Chest wall implantation & 1 & - & NA \\
\hline Kara, 2001[2] & aspiration & NA & $\begin{array}{l}\text { needle track implantation and } \\
\text { metastasis }\end{array}$ & 1 & - & NA \\
\hline $\begin{array}{l}\text { Kim, } \\
2003[33]\end{array}$ & aspiration & NA & chest wall implantation & 9 & $\begin{array}{l}0.21 \% \\
(9 / 4365)\end{array}$ & NA \\
\hline $\begin{array}{l}\text { Matsuguma, } \\
\text { 2005[1] }\end{array}$ & $\begin{array}{l}\text { Core } \\
\text { biopsy }\end{array}$ & 18 & $\begin{array}{l}9 \text { pleural recurrence; } 1 \text { needle } \\
\text { track implantation }\end{array}$ & 10 & $\begin{array}{l}10.75 \% \\
(10 / 93)\end{array}$ & NA \\
\hline $\begin{array}{l}\text { Tomiyama, } \\
\text { 2006[34] }\end{array}$ & $\begin{array}{l}\text { Core } \\
\text { biopsy }\end{array}$ & 18,20 & needle track implantation & 6 & $\begin{array}{l}0.06 \% \\
(6 / 9783)\end{array}$ & NA \\
\hline $\begin{array}{l}\text { Sano, } \\
2009[35]\end{array}$ & $\begin{array}{l}\text { Core } \\
\text { biopsy }\end{array}$ & 20 & 5 pleural dissemination & 5 & $\begin{array}{l}2.92 \% \\
(5 / 171)\end{array}$ & NA \\
\hline $\begin{array}{l}\text { Ibukuro, } \\
2009[36]\end{array}$ & NA & NA & needle track implantation & 4 & $\begin{array}{l}0.56 \% \\
(4 / 713)\end{array}$ & $\begin{array}{l}4-7 \text { months (mean, } \\
5.6 \text { months) }\end{array}$ \\
\hline $\begin{array}{l}\text { Scotti, } \\
2012[37]\end{array}$ & aspiration & NA & chest wall implantation & 1 & - & NA \\
\hline $\begin{array}{l}\text { Schreiner, } \\
2013[38]\end{array}$ & aspiration & NA & chest wall metastasis & 1 & - & NA \\
\hline $\begin{array}{l}\text { Kim, } \\
2014[39]\end{array}$ & NA & 22 & $\begin{array}{l}\text { implantation metastasis in the } \\
\text { pulmonary parenchyma }\end{array}$ & 1 & - & 17 months \\
\hline $\begin{array}{l}\text { Kashiwabara, } \\
2016[40]\end{array}$ & aspiration & 21 & Needle tract implantation & 1 & $1.59 \%(1 / 63)$ & NA \\
\hline $\begin{array}{l}\text { Ahn, } \\
\text { 2019[41] }\end{array}$ & NA & NA & $\begin{array}{l}\text { Concomitant pleural recurrence in } \\
42(5.1 \%) ; \text { isolated pleural } \\
\text { recurrence in } 26(3.1 \%)\end{array}$ & 68 & $\begin{array}{l}12.59 \% \\
(68 / 540)\end{array}$ & NA \\
\hline Huang, & NA & NA & Chest wall implantation & 1 & - & NA \\
\hline
\end{tabular}




\section{Figures}



Figure 1

A The chest CT on April 4, 2016 showed a pulmonary nodule in the left upper lobe;B The lesion was enlarged on June 13, 2016; CPleural and pericardial effusion was indicated on January 9, 2017 after biopsy.

\section{Supplementary Files}

This is a list of supplementary files associated with this preprint. Click to download.

- CAREChecklist.docx 